\title{
IMÁGENES INVERSAS DE ARCIMBOLDO
}

\author{
BARBÓN GARCÍA J ${ }^{1}$
}

Giuseppe Arcimboldo o Arcimboldi (Milán, 1527-1592), fue un pintor italiano que alcanzó gran fama en su época por sus singulares creaciones, y que cayó luego en un profundo olvido hasta ser de nuevo redescubierto y considerado como precursor del surrealismo a principios del s. XX.

Hijo de pintor, en su juventud cultiva la pintura sagrada en Lombardía, donde realiza vidrieras para la Catedral de Milán, frescos en la Catedral de Monza y tapices para la Catedral de Como, antes de convertirse en pintor real. En la Corte de Praga, entre 1562 y 1582, bajo los Emperadores Fernando I, Maximiliano II y Rodolfo II, Arcimboldo empie-

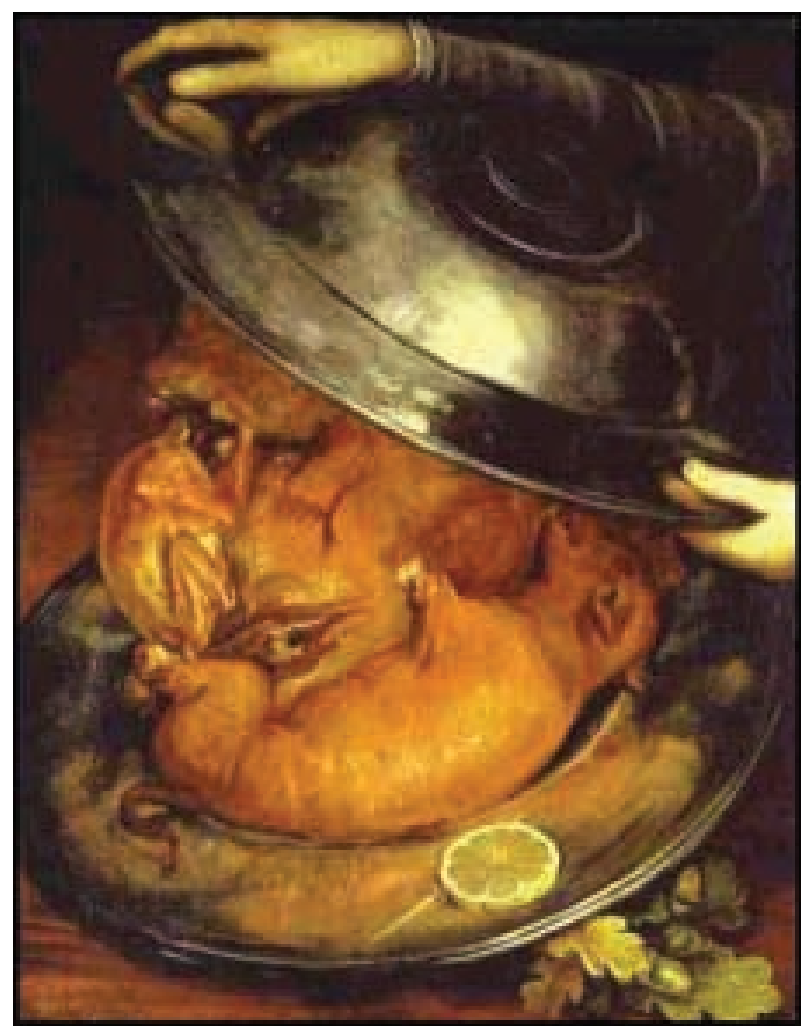

Fig. 1: El asado. Colección privada. Estocolmo, Suecia. za a cultivar, junto a la pintura académica convencional de retratista de la Corte, una singular forma de pintar, sorprendente y caricaturesca, en la que construye el rostro y la figura humana combinando flores, frutas, verduras, animales o libros.

Sus famosas cabezas compuestas son representaciones alegóricas de los elementos y las estaciones que evocan, en las que los rasgos y formas se construyen con una hábil combinación y superposición de objetos. Junto a este tipo de cuadros tan caracte-

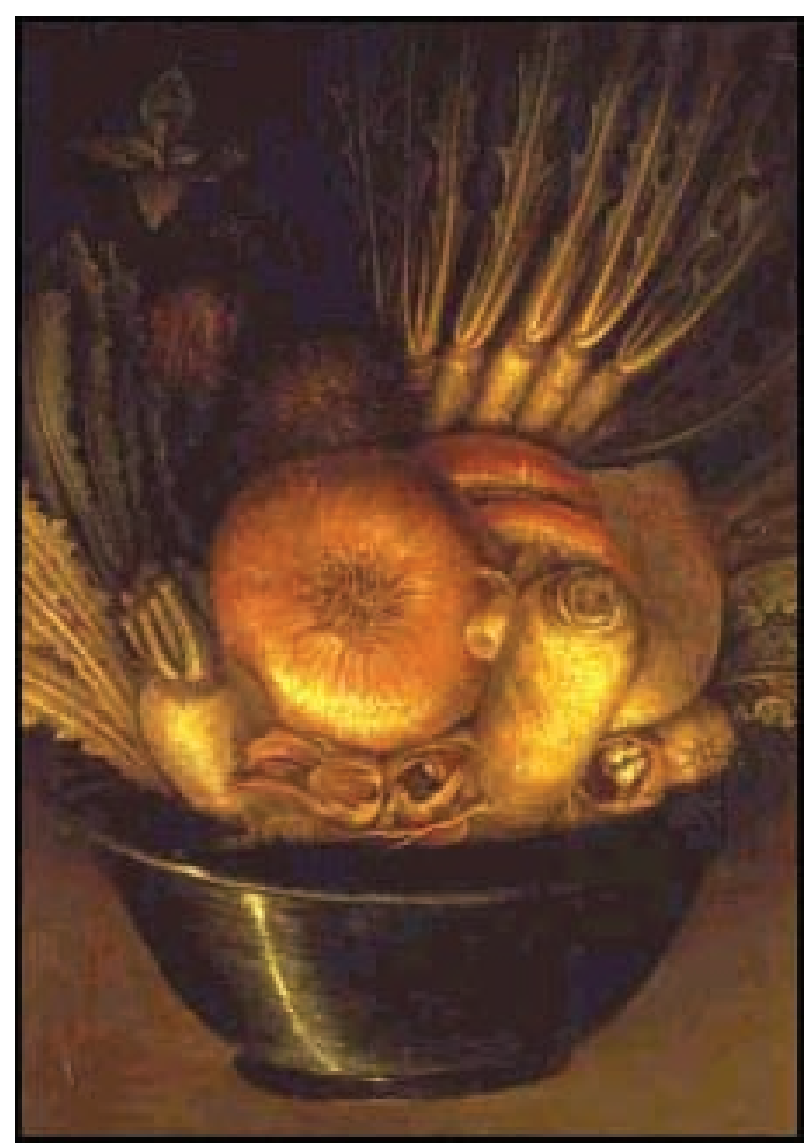

Fig. 2: El hortelano. Museo Cívico. Cremona, Italia.

${ }^{1}$ Oftalmólogo. Hospital San Agustín de Aviles. Asturias. España. E-mail: jjbarbon@telecable.es 
rísticos de su estilo también utiliza efectos ilusionistas, llamados trompe l'oeil, ya que engañan al ojo, como estas imágenes invertidas que generan una nueva figura al rotar el cuadro $180^{\circ}$. En «El asa$d o »$, de 1570, el giro transforma un plato con varias piezas de carne en el momento de ser destapadas, en un tosco rostro humano, y en «El hortelano o Tazón de verduras», pintada sobre 1590 , una fuente repleta de hortalizas se convierte al darle la vuelta en una cabeza de mofletes y nariz prominente, representando a la persona que las cultiva.

\section{BIBLIOGRAFÍA}

- W Kriegeskorte. Arcimboldo. Colonia: Taschen; 2002

- Stefano Zuffi. La naturaleza muerta. Milán: Ed. Electa; 1999

- www.artcyclopedia.com 